\title{
Maastricht lets parliament flex its muscles
}

Brussels. The European Parliament wants to use the new powers given to it when the Maastricht agreement came into force on 1 November to play a bigger role in shaping Community research policy. Previously, control has been exercised mainly by the European Commission, which proposes research programmes, and the Council of Ministers which approves them.

Proposals have been required to go through a double reading in the parliament. But the commission has been able to ignore any amendments the parliament asked for; the only way the parliament has been able to change the programmes has been to threaten to use the double-reading procedure to delay their adoption.

The main new power given to the parliament is that, like individual member states, it can now veto the Framework budget proposal (see Nature 365, 775; 1993). But members of the parliament are keen to dispel the idea that this restricts them to wielding a very large club. Their power of veto, they argue, carries with it the right to shape EC policy from the outset.

If parliament is to do this, however, it must first break the grip that the commission holds over Community research as the body that both proposes and manages programmes. Officials at parliament admit that it does not have the expertise to take over the commission's role in proposing pro-

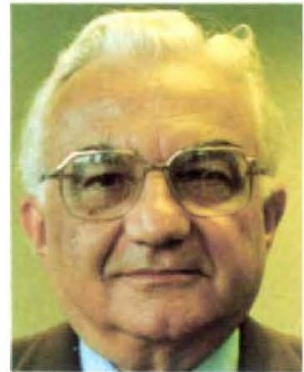

Ruberti: approval from parliament. grammes. But it wants, for example, to stop the self-perpetuating tendency of unproductive programmes.

In particular, the parliament is insisting that the commission takes into account evaluations of the fourth five-year Framework programme, which is meant to start next year made by "external, independent experts qualified in research management", before proposing its successor.

The parliament also wants a bigger say in overseeing research programmes. At present, decisions on who gets what are made in secret by committees composed of national civil servants and chaired by commission officials - a procedure that actively encourages nationalist horsetrading, says one parliamentary official.

Members of parliament were last week informally discussing whether their "powers of scrutiny and control" should extend to their direct participation in these committees. They also say that the committees should meet in public when they are not discussing confidential matters, but only what sort of research to do.

Among the changes that the parliament wants is an increase in research into the social and economic impact of research in the fourth Framework, and an ambitious programme on these topics in the fifth.

Parliament is also broadly in favour of spending more money on life sciences, environment, renewable energy and new industrial technologies, and less on the costly information and communications technology programmes.

Claude Desama, the president of parliament's energy, research and technology committee, says that its relations with the commission have improved since Antonio Ruberti replaced Filippo Pandolfi as research commissioner at the beginning of this year (see Nature 361, 198; 1993).

In particular, he says that the parliament welcomes Ruberti's greater emphasis on fundamental research, the closer integration

of Community programmes with those of national and European research bodies, and its growing attention to the social and economic dimensions of research which it would like increased.

But the parliament feels that Ruberti needs to do more to make the commission's directorates of research and industry cooperate. It also believes that Ruberti has missed an opportunity in the fourth Framework programme to reform the Joint Research Centres, despite long-standing criticism of their relatively low productivity.

If the parliament is to play a greater role in $\mathrm{EC}$ research, it will first have to address its lack of relevant infrastructure and expertise, highlighted in a report last year by Michel Hervé, a French member of the parliament. He also recommended that the parliament be given access to the same information as is currently available to the commission.

Declan Butler

\section{CERN members seek better deal}

Munich. The European Laboratory for Particle Physics (CERN) is considering a proposal that could result in the level of industrial contracts received by its 17 member states being more closely related to their financial contributions.

Last month, Italy formally suggested how such contracts, most of which go to the two host countries, France and Switzerland, could be more equally shared without increasing the cost to CERN. This would be done by giving non-host countries an opportunity to match host-country bids. A working group within CERN's financial committee will make recommendations to the next general council meeting on 17 December.

Contributions to CERN are related to each country's gross national product. The number of scientific staff from each member state is unrelated to the contribution of that country, and construction and servicing contracts are awarded to the lowest bidder.

Some countries, however, feel that the way this works out in practice has not been equitable. In particular, they claim that CERN's location on the border between France and Switzerland gives them a strong advantage when bidding for contracts.

Between 1986 and 1991, for example, France, which currently provides 17 per cent of the laboratory's annual budget of SFr954 million (US\$640 million), received 33 per cent of all contracts. Similarly Switzerland, which contributes less than 4 per cent, received 24 per cent of contracts. In contrast, Germany (which pays 23 per cent of the budget) received only 13 per cent of contracts, the UK (14 per cent) received 7 per cent, Italy ( 17 per cent) received 6 per cent, and Spain ( 8 per cent) only 2 per cent. Italy's delegate on the CERN council, Luciano Maiani, director of Italy's National Institute of Nuclear Physics, says that contracts should still be awarded on the basis of cost but that the system of assessing tenders should give non-member states a fairer chance of winning.

At present, technical specifications are sent to member states and, when sealed tenders are opened, the contract is given to the lowest bidder. Maiani suggests that nonhost countries be given a chance to match a lower bid from a host country; if they can meet it, they should get the contract.

Spain has been the most active member in protesting at the disparity between contributions and returns. It has not paid its membership dues for nearly two years, insisting that either these be reduced, or it should be guaranteed more contracts, while stressing that it is keen to remain an active member.

Spanish scientists have been embarrassed by their government's action, and have been pressing the ministry of industry to pay the country's debts. Later this month Carlo Rubbia, CERN's director general, and William Mitchell, the council's president, will visit Madrid to negotiate repayment.

Cayetano Lopez, Spain's representative on CERN's council, accepts that Spain has a responsibility to pay off its debt in a reasonable time. But he also argues that it is necessary to work out a fairer deal.

Spain is also unhappy that it has less than two per cent of CERN's 3,000 permanent staff. But the principle of hiring staff according to merit rather than country of origin is not under discussion. Alison Abbott 